\title{
A new Hasemania Ellis from the upper rio Paraná basin, with the redescription of Hasemania crenuchoides Zarske \& Géry (Characiformes: Characidae)
}

\author{
Jane Piton Serra ${ }^{1}$ and Francisco Langeani ${ }^{2}$
}

\begin{abstract}
A new Hasemania species is described from the headwaters of the rio Uberaba, rio Grande basin, State of Minas Gerais, Brazil. The new species is distinguished from its congeners by a combination of a black, vertically-elongate humeral spot, a single ossification in the position primitively occupied by infraorbitals four and five, four teeth on the inner series of premaxilla, and scales covering the anal-fin base. Hasemania crenuchoides is redescribed and its known geographic distribution is extended; it can be differentiated from other species of the genus by the combination of a black verticallyelongate humeral spot, ii, 8 dorsal-fin rays, 11-14 branched anal-fin rays, the presence of separate infraorbitals four and five, and the presence of scales covering the anal-fin base. Phylogenetic relationships of H. crenuchoides and the new species within Hasemania are discussed.

Uma nova espécie de Hasemania é descrita para as cabeceiras do rio Uberaba, bacia do rio Grande, estado de Minas Gerais, Brasil. A nova espécie distingue-se de suas congêneres pela combinação de uma mancha umeral preta verticalmente alongada, uma ossificação única na posição primitivamente ocupada pelos infraorbitais quatro e cinco, quatro dentes na série interna do pré-maxilar e escamas cobrindo a base da nadadeira anal. Hasemania crenuchoides é redescrita e sua distribuição geográfica conhecida é ampliada; ela pode ser diferenciada das demais espécies do gênero pela combinação de uma mancha umeral preta verticalmente alongada, ii,8 raios na nadadeira dorsal, 11-14 raios ramificados na nadadeira anal, presença de infraorbitais quatro e cinco distintos e presença de escamas cobrindo a base da nadadeira anal. As relações filogenéticas de H. crenuchoides e da nova espécie são discutidas dentro de Hasemania.
\end{abstract}

Keywords: Freshwater fish, Headwaters, Rio Grande, Rio Uberaba.

\section{Introduction}

Hasemania Ellis is a small genus of the Characidae restricted to the rivers of the Crystaline Brazilian Shield. The genus was proposed by Ellis (1911) to include three species, H. melanura Ellis (type species), H. maxillaris Ellis and $H$. bilineata Ellis, and differed from all other characids primarily in the absence of the adipose fin. Ellis (1911) further defined the genus by having two rows of premaxillary teeth, few or no teeth along the upper angle of the maxillary, an incomplete lateral line, the caudal fin naked, and a frequently larval pectoral fin in small specimens. Hasemania now includes eight species: $H$. melanura and H. maxillaris, from the rio Iguaçu basin, $H$. nana (Lütken) from the rio São Francisco basin, $H$. hanseni (Fowler) from Goiás (precise locality unknown), H. crenuchoides Zarske \& Géry, from the upper rio Paraná basin, H. nambiquara Bertaco \& Malabarba, from the upper rio Tapajós basin, H. piatan Zanata \& Serra, from the rio de Contas basin, and H. kalunga Bertaco \& Carvalho, from the upper rio Tocantins.

Hasemania crenuchoides was until recently only known from its type specimens, and these specimens exhibit a very clear brown staining, without any spot in the body or fins. Zarske \& Géry (1999), in the original description of this species, mentioned the specimens preserved for more than thirty years, having a uniform yellowish to olive green coloration, without spots. Recently, Langeani et al. (2007), cited this species from headwaters of the rio Uberaba, rio Grande basin, State of Minas Gerais. Numerous other specimens were subsequently collected in the córrego Paranoazinho, rio Paranaíba drainage, near the type locality of the species; these specimens showing a conspicuous color pattern, including a black humeral spot.

${ }^{1}$ Instituto Federal de Educação, Ciência e Tecnologia do Sul de Minas Gerais (IFSULDEMINAS), Campus Poços de Caldas, Rua Dirce Pereira Rosa, 300, 37713-100 Poços de Caldas, MG, Brazil. jane.sanches@ifsuldeminas.edu.br (corresponding author)

${ }^{2}$ Universidade Estadual Paulista (UNESP), Laboratório de Ictiologia, Departamento de Zoologia e Botânica, Rua Cristóvão Colombo, 2265, 15054-000 São José do Rio Preto, SP, Brazil. langeani@ibilce.unesp.br 
The analysis of this material revealed that the specimens from the rio Paranaíba basin are indeed $H$. crenuchoides, whereas samples from the rio Grande basin represents a new species, which is described herein together with a redescription of $H$. crenuchoides.

\section{Material and Methods}

Counts and measurements follow Fink \& Weitzman (1974). Vertebrae, branchiostegal rays, gill-rakers, total dentary teeth counts and teeth cusp numbers were taken from cleared and stained specimens (c\&s) prepared according to Taylor \& Van Dyke (1985). All measurements were taken point-to-point with an electronic caliper on the left side of specimens. Standard length (SL) is presented in $\mathrm{mm}$, and the other measurements are expressed as percentages of the SL, except for subunits of head which are presented as percentages of the head length (HL). Vertebral count includes the Weberian apparatus as four elements and the fused PU1+U1 as a single element. Meristic data are presented in the description and are followed by the frequency for each count in parenthesis. An asterisk indicates counts of the holotype. Larger specimens were dissected to observe the gonads for sex determination.

Examined specimens are deposited in the collections of the Departamento de Zoologia e Botânica da UNESP de São José do Rio Preto, São José Rio Preto (DZSJRP); Museu de Zoologia da Universidade de São Paulo, São Paulo (MZUSP), Museum d'Histoire Naturelle, Genève (MHNG); Academy of Natural Sciences of Drexel University, Philadelphia (ANSP); Field Museum of Natural History, Chicago (FMNH); and Museu de Ciências e Tecnologia da Pontifícia Universidade Católica do Rio Grande do Sul, Porto Alegre (MCP).

\section{Results}

\section{Hasemania uberaba, new species}

urn:1sid:zoobank.org:act:5515B222-B4F3-4858-AB31903B44F7F508

Figs. 1-3

Hasemania crenuchoides non Zarske \& Géry, 1999: Langeani et al., 2007 (119: fig. 1; 119 and 120: rio Grande basin; 121: morphometrics and meristics comparisons with $H$. crenuchoides holotype (MZUSP 52723) and two paratypes (MHNG 2594.044).

Hasemania melanura non Ellis, 1911: Uieda et al., 1987 (rio Claro, rio Paranaíba basin; 101: fig. 2A; 102: reference; 107: tab. IV and 108: tab. V, stomach contents).

Holotype. DZSJRP 18781, male, $70 \mathrm{~mm} \mathrm{SL}$, Brazil, Minas Gerais, Ponte Alta, Serra do Grotão, road BR 262, headwaters of rio Uberaba, córrego São Pedro, rio Grande basin, upper rio Paraná, $1020 \mathrm{~m}$ a.s.1., 1940'59"S 47040'09”W, 15 Feb 2013, D. C. Ribeiro.
Paratypes. DZSJRP 8730, 133 (4 c\&s), 29.6-62.4 mm SL, 30.9-43.8 mm SL, same locality as holotype, 8 Sep 2006, F. Langeani, J. P. Serra-Sanches, F. R. Carvalho, H. F. Chaves, C. P. Ferreira \& F. O. Martins. DZSJRP 15803, 66, 14.2$52.4 \mathrm{~mm}$ SL, same locality as holotype, $11 \mathrm{Mar} 2012$, F. Langeani, F. O. Martins \& F. R. Carvalho. DZSJRP 19239, 5, 33.9-54.1 mm SL, collected with the holotype.

Diagnosis. Hasemania uberaba is distinguished from congeners by having a black, vertically-elongate humeral spot (vs. spot absent except for H. crenuchoides, H. kalunga, $H$. nambiquara, and $H$. piatan), a single ossification in the position primitively occupied by infraorbitals four and five ( $v s$. infraorbitals four and five separate, except in $H$. kalunga and $H$. piatan), 4 inner row premaxillary teeth (vs. 5 except in $H$. nana, $H$. melanura, and $H$. piatan), and scales covering the anal-fin base (vs. scales absent except in $H$. crenuchoides, $H$. hanseni, $H$. maxillaris, $H$. melanura, $H$. nambiquara, and $H$. nana). Hasemania uberaba can be also distinguished from $H$. kalunga and $H$. piatan by having $14-$ 18 circumpeduncular scales (vs. 10-12); from $H$. hanseni, $H$. maxillaris, and $H$. nambiquara by having $10-15$ branched anal-fin rays (vs. 16-19); from $H$. hanseni, H. melanura, and $H$. nana by having 6-10 scales covering the anal-fin base (vs. 2-5), and from $H$. maxillaris and $H$. nambiquara by having 7-8 branched dorsal-fin rays (vs. 9). Additionally, H. uberaba differs from $H$. melanura by having maxillary teeth ( $v$. absent); from $H$. maxillaris by having, 6-7 branched pelvicfin rays (vs. 5), from $H$. nambiquara by the absence of a broad black band in the midlateral line, from the humeral region to the caudal-fin ( $v s$. presence of such band). Finally, most specimens of $H$. uberaba have 18 principal caudal-fin rays (vs. 19 in most other species except $H$. piatan).

Description. Morphometric data in Table 1. Body deep and transversely rounded; greatest body depth between tip of supraoccipital spine and dorsal-fin origin. Head moderately deep, rounded anteriorly in lateral profile; eye small. Dorsal profile of head distinctly convex from margin of upper lip to region of vertical through anterior nostril, straight to slightly concave from that point to posterior tip of supraoccipital spine in mature males and immatures, greatly concave in mature females. Dorsal profile of head and body slightly convex from tip of supraoccipital spine to dorsal-fin origin, posteroventrally inclined along dorsalfin base, straight from terminus of dorsal-fin base to origin of caudal-fin rays. Ventral profile of head and body convex from margin of lower lip to posterior terminus of anal-fin base. Ventral profile of caudal peduncle slightly concave. Infraorbital series incomplete, with only four bones, single ossification in position primitively occupied by infraorbitals four and five and infraorbital 6 absent. Rhinosphenoid cartilaginous.

Jaws equal, mouth terminal. Premaxillary dentition in two rows. Outer row with $3(4)$ or $4 *(28)$ tricuspid teeth and inner row with $4 *(31)$ or 5 (1) teeth with 3 to 6 cups. 
Maxilla with 1(5), 2(17), 3(8), 4(1) or $5^{*}(1)$ teeth bearing 1 to 6 cusps. Dentary with $4 *(32)$ larger teeth anteriorly with 4 or 5 cusps, followed by 5 to 9 distinctly smaller teeth with 1 to 3 cusps.

Dorsal-fin rays ii,7(1) or ii, $8^{*}(32)$. Distal margin of dorsal fin usually rounded. Anal-fin rays iii-iv,10(1), 11(2), $12(3), 13(14), 14 *(9)$ or $15(4)$. Pectoral-fin rays i, 10(6), $11^{*}(22)$ or $12(5)$. Tip of pectoral fin falling short of vertical through pelvic-fin insertion. Pelvic-fin rays i, $6^{*}(27)$ or 7(4). Caudal fin forked, lobes rounded and of similar size. Principal caudal-fin rays i,8/7,i(2); i,8/8/,i*(43); i,9/8,i(5). Adipose fin absent.

Scales cycloid. Lateral line incomplete. Pored scales $8(3), 9(8), 10(6), 11(1), 12(7), 13(4), 14 *(1)$ or 15(1). Longitudinal scale series including perforated scales $28(2)$, 29(2), 30(9), 31(5), 32(6), 33(3), 34(3) or 35*(1). Horizontal scale rows between lateral line and dorsal-fin origin $5^{*}(15)$ or 6(17). Horizontal scale rows between lateral line and pelvic-fin origin $4(23)$ or $5^{*}(9)$. Scale sheath along basal portion of anal-fin rays with $6(2), 7(5), 8^{*}(7), 9(7)$ or 10(3) scales in single series. Scales between tip of supraoccipital process and dorsal-fin origin 10(2), 11(5), 12*(10), 13(1), 14(3), 15(1) or 16(1). Horizontal scale rows around caudal peduncle 14(2), 15(8), 16*(17), 17(1) or 18(1). Scales present only over caudal-fin base. Vertebrae 34(2) or 35(2). First gill arch with 6(2) epibranchial, 8(2) ceratobranquial, 1(2) on cartilage between ceratobranchial and epibranchial, and 2(2) hypobranchial gill-rakers. Supraneurals 5(2) or 6(2).

Color in alcohol. Preserved specimens with dark bodies, chromatophores concentrated mainly dorsally and along pattern. Irregular, vertically elongate humeral spot. Longitudinal, mid-lateral stripe extending from vertical midway between head and dorsal-fin origin posteriorly to middle caudal-fin rays. Fins with chromatophores more concentrated along rays than on membranes (Figs. 1-2). posterior margin of scales, resulting in slightly reticulated

Color in life. Live specimens have conspicuous reticulated color pattern, scales with metallic bluish-purple reflections. Dorsal, anal, and caudal fins, mainly the last one, reddish with dark rays.

Sexual dimorphism. Females with a conspicuous concavity along dorsal profile between vertical passing through the posterior nostril to the posterior portion of the head (Fig. 2). Bony hooks along pelvic and anal-fin rays were not observed in any specimen.

Table 1. Morphometric data for holotype $(\mathrm{H})$ and 32 paratypes of Hasemania uberaba. $\mathrm{SD}=$ standard deviation. Range includes holotype.

\begin{tabular}{lcccc}
\hline & H & Range & Mean & SD \\
\hline Standard length (mm) & 70.0 & $26.9-70.0$ & 43.3 & \\
& Percents of Standard length & & \\
Body depth & 34.7 & $33.5-39.6$ & 36.3 & 1.5 \\
Head length & 31.7 & $30.1-33.7$ & 31.8 & 1.0 \\
Predorsal distance & 58.6 & $52.7-61.0$ & 58.0 & 1.5 \\
Preventral distance & 53.9 & $48.6-55.1$ & 52.7 & 1.5 \\
Pelvic-anal fin distance & 18.4 & $17.2-22.6$ & 19.5 & 1.3 \\
Caudal-peduncle depth & 13.6 & $13.5-15.7$ & 14.6 & 0.6 \\
Caudal-peduncle length & 12.0 & $12.0-18.7$ & 15.2 & 1.4 \\
Dorsal-fin base length & 11.7 & $10.9-15.9$ & 12.5 & 1.0 \\
Anal-fin base length & 18.4 & $18.0-21.9$ & 19.9 & 1.1 \\
Pectoral-fin length & 17.4 & $14.4-20.4$ & 16.5 & 1.2 \\
Pelvic-fin length & 13.9 & $12.5-16.0$ & 14.3 & 0.9 \\
Dorsal-fin length & 21.4 & $21.4-28.7$ & 24.7 & 1.7 \\
Anal-fin length & 16.4 & $15.2-20.2$ & 18.2 & 1.3 \\
Caudal-fin length & 20.6 & $16.5-22.0$ & 19.2 & 1.3 \\
& Percents of Head length & & \\
Head depth & 82.0 & $82.0-96.5$ & 91.4 & 3.0 \\
Orbital diameter & 21.2 & $21.2-33.9$ & 28.7 & 2.5 \\
Snout length & 23.9 & $19.0-26.1$ & 22.5 & 1.9 \\
Interorbital width & 31.5 & $26.9-34.0$ & 31.0 & 1.6 \\
\hline & \multicolumn{5}{c}{} &
\end{tabular}

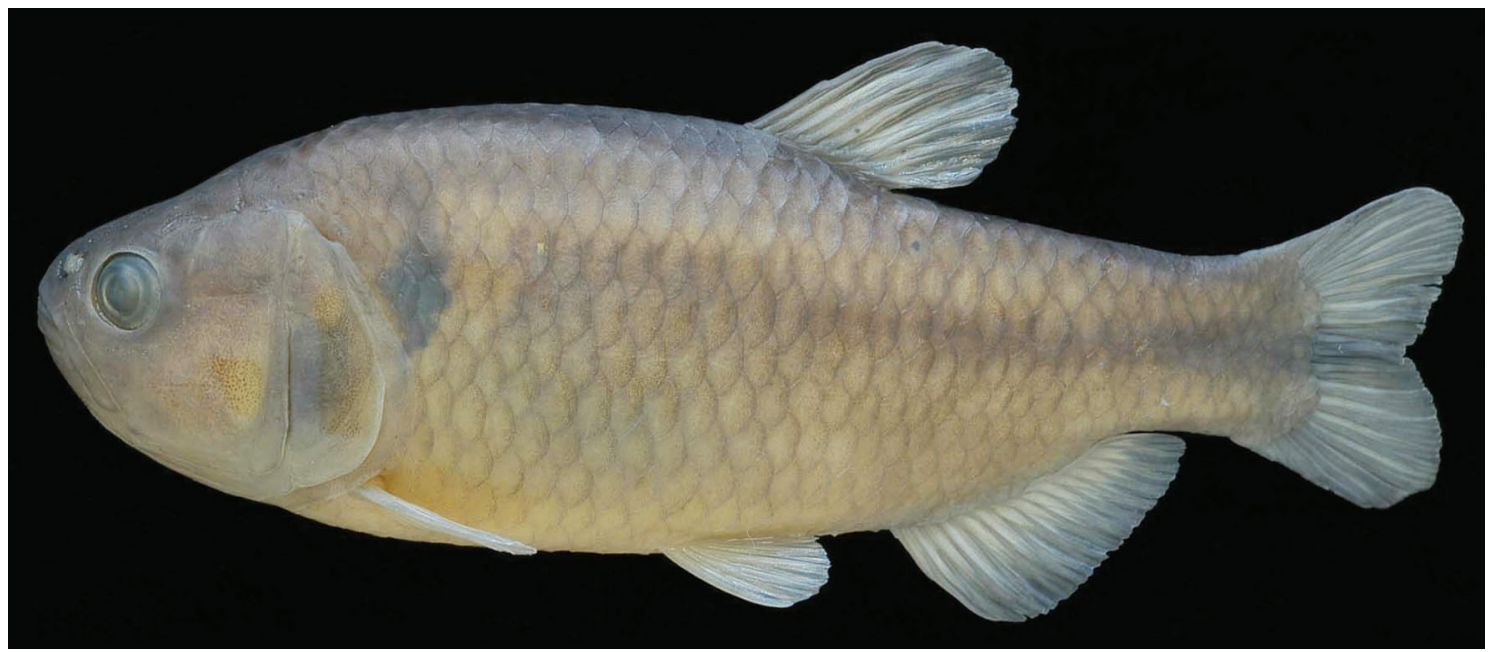

Fig. 1. Hasemania uberaba, holotype, DZSJRP 18781, male, $70.0 \mathrm{~mm}$ SL, Brazil, Minas Gerais State, Ponte Alta, Serra do Grotão, road BR 262, headwaters of rio Uberaba, córrego São Pedro, rio Grande basin, upper rio Paraná basin. 


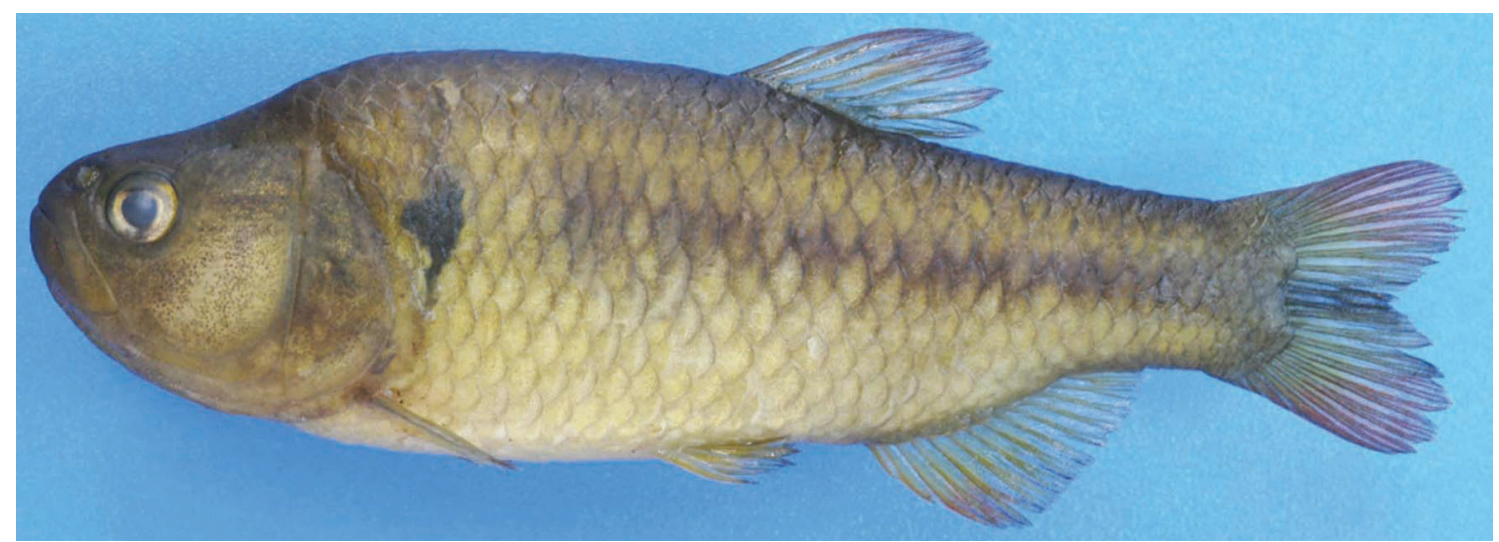

Fig. 2. Hasemania uberaba, paratype, recently fixed specimen, DZSJRP 8730, female, $62.4 \mathrm{~mm}$ SL, Brazil, Minas Gerais State, Ponte Alta, Serra do Grotão, road BR 262, headwaters of rio Uberaba, córrego São Pedro, rio Grande basin, upper rio Paraná basin.

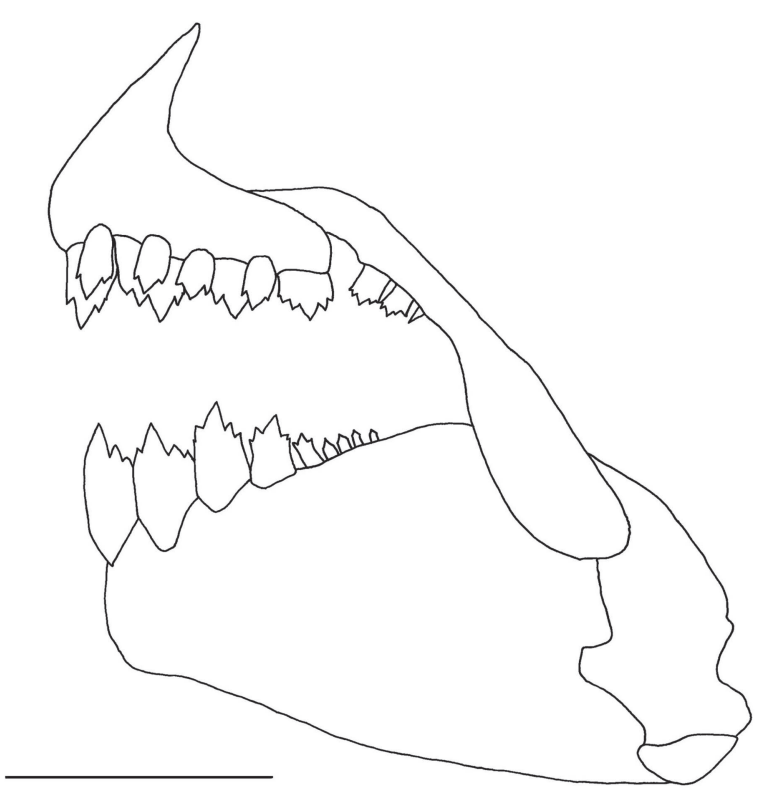

Fig. 3. Jaws of Hasemania uberaba, left side, paratype, DZSJRP 8730, $36.8 \mathrm{~mm}$ SL. Scale bar $=1.5 \mathrm{~mm}$.

Distribution. Hasemania uberaba is only known from its type locality in the headwaters of the rio Uberaba, rio Grande basin, upper rio Paraná basin, Minas Gerais, Brazil (see Carvalho \& Langeani, 2013: figs. 4-5).

Ecological notes. Headwaters of the rio Uberaba are a marshland with abundant Cyperacea, Poacea and algae, crystalline water and muddy bottom (Carvalho \& Langeani, 2013: fig. 5). Hasemania uberaba was captured jointly with a new genus and new species of Crenuchidae, the most abundant species (under analysis), Hyphessobrycon uaiso Carvalho \& Langeani, and Rivulus sp. The larger, less numerous, specimens among $H$. uberaba could be easily seen among the smaller specimens of the other species. They swim in open water or sheltered areas with submerged vegetation. Among the specimens examined for stomach contents, one consumed angiosperms and Chironomidae larvae (Diptera), other angiosperms and Trichoptera, and one mostly Diptera larvae, followed by angiosperms and tecamoebas; Uieda et al. (1987: tables IV and V) refer to algae, Ephemeroptera, Odonata, Trichoptera, Diptera, Megaloptera, and organic matter (autochthonous items) and angiosperms, Coleoptera, Trichoptera, and Hymenoptera (allochthonous items) in the stomachs of the specimens of the species they examined (identified therein as H. melanura).

Etymology. The species name, uberaba, is in reference to the rio Uberaba, where the species is found. A noun in apposition.

Conservation status. Hasemania uberaba until now was only confirmed to occur in the type-locality (area of occupancy AOO less than $10 \mathrm{~km} 2$ ). There is a putative new reference for the species, based on a fish drawing (fig. 2A, Uieda et al., 1987, referred as Hasemania melanura), in the rio Claro, rio Paranaíba basin, a locality very near the type-locality; this additional occurrence, however, could not be confirmed because the specimens analyzed by Uieda et al. (1987) were not conserved and all recent efforts to collect the species in the rio Claro were unsuccessful. The small geographic area (one location) harbors a very peculiar kind of habitat (see "Ecological notes" above) and is limited by a paved road (BR 262) and land areas with agriculture. Furthermore, the waters of the rio Uberaba are used by human consumption and since the southeastern Brazil is suffering a long drought (Escobar, 2015), this can contribute to a decay of the water levels in the basin, which now seems to be a serious plausible threat that can drive the species to critically endangered or extinct in a very short time, allowing to its classification as Vulnerable (VU D2) according to the IUCN $(2001,2011)$. In spite of that, it is now preferable to consider Hasemania uberaba as Data Deficient (DD) until more information about its biology and geographical distribution is available, as already pointed out by Carvalho \& Langeani (2013) for Hyphessobrycon uaiso, a syntopic characid species. 


\section{Hasemania crenuchoides Zarske \& Géry, 1999}

Figs. 4-5

Hasemania crenuchoides Zarske \& Géry, 1999 (original description, type locality: corrego Planaltina, oberer rio São Bartolomeu (mündend in den rio Corumba, Nebenfluss des rio Paranaiba, La-Plata system), $1050 \mathrm{~m}$ über NN, nahe Planaltina, nordöstl. von Brasilia, Distrito Federal, Bundesstaat Goias, Brasilien, etwa $15^{\circ} 38^{\prime}$ südl. Breite und 47 40' westl. Länge); Lima et al., 2003 (128: check list for the genus); Bertaco \& Malabarba, 2007 (compared to H. nambiquara); Langeani et al., 2007 (partim, 121: holotype (MZUSP 52723) and two paratypes (MHNG 2594.044) morphometrics and meristics comparisons with Hasemania specimens from rio Grande (= Hasemania uberaba); Bertaco \& Carvalho, 2010 (compared to $H$. kalunga); Langeani \& Serra, 2010 (733: rhinosphenoid bone comparisons with Coptobrycon bilineatus); Zanata \& Serra, 2010 (compared to H. piatan).

Diagnosis. Hasemania crenuchoides is distinguished from its congeners by having a black vertically-elongate humeral spot ( $v$ s. absent, except from $H$. kalunga, $H$. nambiquara, $H$. piatan, and $H$. uberaba), ii,8 dorsal-fin rays (vs. ii,9, except $H$. hanseni, $H$. kalunga, $H$. melanura, $H$. nana, and $H$. uberaba); 11-14 branched anal-fin rays (vs. 16-19, except $H$. kalunga, $H$. melanura, $H$. nana, $H$. piatan, and $H$. uberaba), infraorbitals four and five (vs. a single ossification in the position occupied by infraorbitals four and five, except $H$. hanseni, $H$. maxillaris, $H$. melanura, $H$. nambiquara, and $H$. nana), and presence of scales covering the anal-fin base ( $v$ s. absent, except $H$. hanseni, H. maxillaris, H. melanura, $H$. nambiquara, $H$. nana, and H. uberaba). Additionally, $H$. crenuchoides differs from $H$. melanura by having maxillary teeth (vs. absent); from $H$. nambiquara by the absence of a broad black band in the midlateral line, from the humeral region to the caudalfin (vs. presence), and from $H$. piatan by possessing 19 principal caudal-fin rays (vs. 18).

Description. Morphometric data in Table 2. Body deep and transversely rounded. Greatest body depth between tip of supraoccipital spine and dorsal-fin origin. Head moderately deep and rounded anteriorly in lateral profile; eye small. Dorsal profile of head distinctly convex from margin of upper lip to region of vertical through anterior nostril, nearly straight from that point to tip of supraoccipital spine. Dorsal profile of body slightly convex from tip of supraoccipital spine to dorsal-fin origin, posteroventrally inclined along dorsal-fin base, straight from terminus of dorsal-fin base to origin of caudal-fin rays. Ventral profile of head and body convex from margin of lower lip to analfin origin, straight and posterodorsally inclined along analfin base, nearly straight in caudal peduncle. Infraorbital series complete. Rhinosphenoid cartilaginous.
Table 2. Morphometric data of holotype (H) (MZUSP 52732), paratypes (MHNG 2594.044) and non-type specimens (DZSJRP 11039 and DZSJRP 14185) of Hasemania crenuchoides. $\mathrm{SD}=$ standard deviation, $\mathrm{N}=38$ including the holotype and paratypes.

\begin{tabular}{lccccc}
\hline & H & Paratypes & Range & Mean & SD \\
Standard length (mm) & 63.7 & $28.0-38.0$ & $28.0-63.7$ & 41.9 & \\
& Percents & of Standard length & & \\
Body depth & 34.4 & $32.8-36.0$ & $27.8-36.1$ & 31.4 & 1.7 \\
Head length & 29.7 & $27.9-30.0$ & $26.2-30.0$ & 28.0 & 0.9 \\
Predorsal distance & 56.8 & $52.6-55.0$ & $50.1-56.8$ & 52.6 & 1.3 \\
Preventral distance & 51.2 & $48.4-50.0$ & $47.1-51.9$ & 49.5 & 1.1 \\
Pelvic-anal fin distance & 16.5 & $17.5-18.2$ & $15.3-19.5$ & 17.4 & 1.0 \\
Caudal-peduncle depth & 14.3 & $12.8-12.9$ & $12.2-14.3$ & 13.3 & 0.5 \\
Caudal-peduncle length & 15.7 & $17.5-17.6$ & $12.8-18.1$ & 16.2 & 1.1 \\
Dorsal-fin base length & 12.6 & $9.7-10.0$ & $9.7-15.0$ & 13.1 & 1.3 \\
Anal-fin base length & 18.7 & $18.9-19.5$ & $17.5-22.7$ & 19.9 & 1.3 \\
Pectoral-fin length & 18.2 & $18.7-21.1$ & $18.2-22.5$ & 20.3 & 1.1 \\
Pelvic-fin length & 14.1 & $13.4-14.3$ & $10.1-17.9$ & 15.2 & 1.4 \\
Dorsal-fin length & 21.4 & $21.3-23.9$ & $21.3-28.6$ & 25.4 & 1.7 \\
Anal-fin length & 16.0 & $16.8-17.6$ & $16-21.6$ & 19.2 & 1.4 \\
Caudal-fin length & 20.4 & $18.9-22.5$ & $18.2-24.2$ & 21.1 & 1.5 \\
& Percents & of Head length & & \\
Head depth & 97.9 & $85.7-94.3$ & $85.6-97.9$ & 90.3 & 2.9 \\
Orbital diameter & 25.4 & 32.1 & $25.4-34.8$ & 31.3 & 2.0 \\
Snout length & 26.5 & 22.6 & $20.2-26.5$ & 22.6 & 1.3 \\
Interorbital width & 33.9 & $32.1-34.0$ & $30.9-35.5$ & 33.2 & 1.3 \\
\hline & & & & & \\
\hline
\end{tabular}

Jaws equal, mouth terminal. Premaxillary dentition in two rows. Outer row with $3(4), 4 *(25)$ or $5(1)$ tricuspid teeth and inner row with $5 *(30)$ irregularly placed teeth with 5 cusps. Maxilla with $1(4), 2 *(24), 3(4)$, or 4(1) tricuspid teeth along anterior dentigerous portion of bone. Dentary with single row of $4 *(27)$ or 5(4) larger teeth with 5 cusps anteriorly followed by $5(2)$ or 6(2) distinctly smaller ones, with 1 or 3 cusps.

Dorsal-fin rays ii, $8 *(38)$. Anal fin short, iii-iv,11(3), $12 *(24), 13(9)$, or 14(2) rays. Caudal fin forked, lobes rounded and similar in size, with some scales covering basal portion of rays. Principal caudal-fin rays i,8/8,i(1); i,9/8,i(33); or i,9/9/i*(1). Pectoral-fin rays i,9(5), 10(16), 11*(16) or 12(1), its tip falling short of pelvic-fin insertion. Pelvic-fin rays i,5(4), 6(32) or $7 *(1)$. Adipose fin absent.

Scales cycloid. Lateral line incomplete. Pored scales: 5(1), 7(1), 9(2), 11(3), 12*(9), 13(7), 14(5), 15(4), 16(4) or 17(2). Longitudinal scale series including perforated scales 20(1), 22(2), 23(5), 24(4), 25(10), 26(7), 27*(5), 28(1), 29(1), 31(1) or 33(1) . Horizontal scale rows between lateral line and dorsal-fin origin 4(1) or $5^{*}(37)$. Horizontal scale rows between lateral line and pelvic-fin origin $4 *(38)$. Scale sheath along basal portion of anal-fin rays with $4 *(6), 5(12)$, $6(12), 7(5), 8(2)$ or 9(1) scales in single series. Horizontal scale rows around caudal peduncle 13(3), 14*(34) or 15(1). 
Scales between tip of supraoccipital process and dorsalfin origin 10(6), 11(13), 12(11), 13*(1) or 14(1). Vertebrae 33(2) or 34(2). First gill arch with 6(2) epibranchial, 8(2) ceratobranquial, 1(2) on cartilage between ceratobranchial and epibranchial, and 2(2) hypobranchial gill-rakers.

Color in alcohol. Based on recently collected specimens. Preserved specimens with yellowish bodies and darkbrown chromatophores concentrated more dorsally and along posterior margin of scales (mainly in midportion), resulting in slightly reticulated pattern on body; humeral spot irregular, inconspicuous and vertically elongated, midlateral stripe extending from slightly behind humeral spot to middle caudal-fin rays. Fins with chromatophores more concentrated along rays than on membranes (Figs. 4-5).
Color in life. Body and head yellowish, more so along ventral portion of head, opercular series and anterior portion of body. Pectoral fin yellowish. Dorsal fin mostly hyaline. Pelvic fin reddish to yellowish. Anal fin red overall but turning yellowish along posteriormost rays. Caudal fin reddish along most superior and inferior rays and yellowish along median ones.

Sexual dimorphism. No secondary sexual characters were observed.

Distribution. Hasemania crenuchoides seems to be restricted to the streams from the upper rio Paraná and upper rio Tocantins in the Distrito Federal, Brazil. This is the first reference to the species for the rio Tocantins basin.

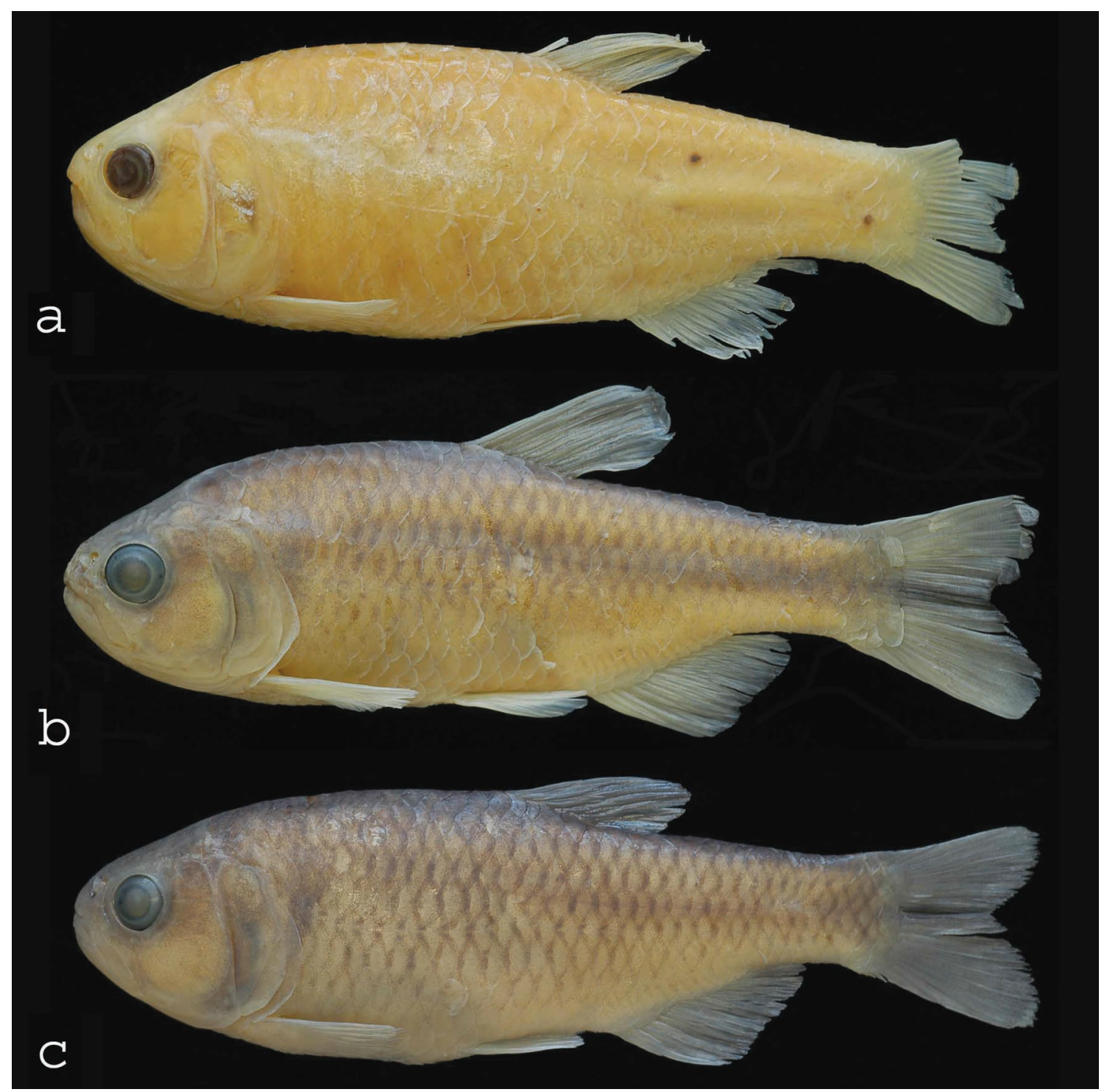

Fig. 4. Hasemania crenuchoides, all from Brazil, Distrito Federal, rio Paranaíba system, upper rio Paraná basin: (a) holotype, MZUSP 52732, male, 63.7 mm SL, córrego Planaltina, rio São Bartolomeu, rio Corumbá drainage; (b) DZSJRP 11039, female, 57.9 mm SL, córrego Paranoazinho, tributary of rio Sobradinho, rio São Bartolomeu basin. rio Maranhão system, rio Tocantins basin; (c) DZSJRP 14185, female, 64.5 mm SL, ribeirão da Contagem, Contagem Biological Reserve. 


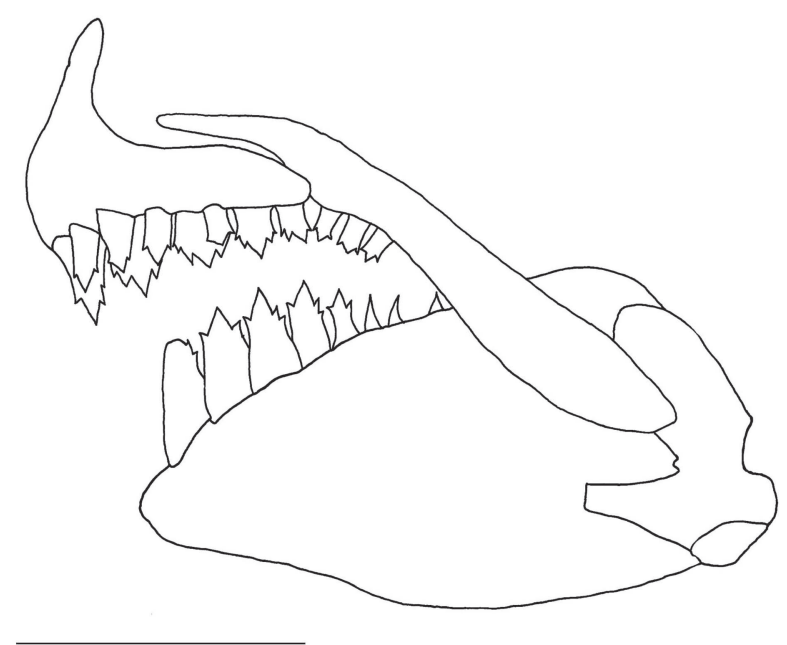

Fig. 5. Jaws of Hasemania crenuchoides, left side, DZSJRP $11039,51.5 \mathrm{~mm}$ SL. Scale bar $=2 \mathrm{~mm}$.

Material Examined. Brazil: Distrito Federal: Upper rio Paraná drainage. DZSJRP 11039, 47 (4 c\&s, 33.8-50.7 mm SL) 20.3-58.0 mm SL, and DZSJRP 14222, 4, 42.9-52.9 mm SL, córrego Paranoazinho, tributary of rio Sobradinho. MHNG 2594.044, 2 of 5 paratypes, 28.0 and $38.0 \mathrm{~mm} \mathrm{SL}$; and MZUSP 52732, $63.7 \mathrm{~mm}$ SL, holotype, male, córrego Planaltina. Upper rio Tocantins drainage. DZSJRP 14185, 20, 35.6-78.2 mm SL, ribeirão da Contagem, Contagem Biological Reserve.

\section{Discussion}

The relationships of Hasemania uberaba and $H$. crenuchoides within the genus remain to be investigated. Nevertheless, the two species are probably closely related to $H$. piatan and $H$. kalunga, by sharing an apparently derived character, the presence of a rhinosphenoid entirely cartilaginous ( $v s$. ossified). In the other species of Hasemania and small characids the rhinosphenoid is completely ossified, whereas in $H$. uberaba, H. crenuchoides, $H$. piatan, and $H$. kalunga a cartilage occurs in the position primitively occupied by the bone. Additionally, H. uberaba, H. kalunga and $H$. piatan share the presence of a single ossification in the position primitively occupied by infraorbitals four and five. Hasemania uberaba and H. piatan, in turn, share 18 principal caudal-fin rays ( $v s .19$ in other congeners, and most other characids and characiforms). Zanata \& Serra (2010) have already proposed $H$. piatan as probably phylogenetically close to $H$. crenuchoides based in the presence of five infraorbitals and a cartilaginous rhinosphenoid. In spite of that, $H$. crenuchoides, H. uberaba, H. kalunga and H. piatan seem indeed to be closely related based on a combination of cartilaginous rhinosphenoid, larger and deeper bodies, and similar color pattern, with an irregular and vertically elongated humeral spot (vs. rhinosphenoid osseous, body shallow and small and humeral spot absent or rounded and horizontally elongated).
The monophyly of Hasemania based mainly on the absence of an adipose fin has been questioned by several authors (Böhlke, 1958; Géry, 1972, 1977; Weitzman \& Malabarba, 1999; Lima \& Gerhard, 2001). As a consequence, Lima \& Gerhard (2001) described Hyphessobrycon negodagua, a species lacking the adipose fin, and maintain it within Hyphessobrycon. Even Ellis (1911), in the same paper in which she proposed Hasemania, described another characid fish lacking an adipose fin as Hyphessobrycon taurocephalus without further explanation. Despite being allocated to Hyphessobrycon, $H$. negodagua and $H$. taurocephalus are traditionally compared with Hasemania species due to the absence of adipose fin. Hasemania crenuchoides differs from Hyphessobrycon negodagua in its color pattern, by having 11-14 branched anal-fin rays ( $v s$. 14-17), and the anal-fin base length $15.5-22.7 \%$ of SL ( $v s$. 25.4-33.2\%); from $H$. taurocephalus in its color patterns and by having ii, 8 dorsal-fin rays (vs. ii,9). Hasemania uberaba differs from $H$. negodagua in its color pattern, by having 18 principal caudal-fin rays (vs. 19), 6-10 scales in the anal-fin base (vs. 3-5), the orbital diameter $21.2-33.9 \%$ of HL (vs. 39.1-48.4\%) and the anal-fin base length $18.0-21.9 \%$ of SL (vs. 25.4-33.2\%); from H. taurocephalus by having 18 principal caudal-fin rays (vs. 19), eight dorsal-fin rays (vs. 9) and the head length $30.1-33.7 \%$ of SL (vs. 26.3-29.2\%).

Furthermore, Hasemania crenuchoides and H. uberaba lack the synapomorphies used to diagnose other characid groups lacking the adipose fin, e.g. a few Cheirodontinae (Malabarba, 1998); a few Xenurobryconini (Weitzman \& Fink, 1985); Nematobrycon Eigenmann and Grundulus Valenciennes (Mirande, 2010); and Coptobrycon Géry (Langeani \& Serra, 2010).

Comparative Material Examined. Brazil: Hasemania hanseni. ANSP 72105, 3, paratypes, 27.7-28.3 mm SL, Goiás. MZUSP 35676, 268, 2 c\&s, 21.8-33.0 mm SL, Distrito Federal, córrego Pipiripau. Hasemania kalunga. DZSJRP 12339, 12, paratypes, 19.8-38.6 mm SL, 1 c\&s, $34.2 \mathrm{~mm}$ SL, Goiás, tributary of rio das Almas. Hasemania maxillaris. FMNH 54303, holotype, 24.4 mm SL, Paraná, rio Iguaçu. Hasemania melanura. FMNH 54385, 39, paratypes, 2 c\&s, 18.2-35.4 mm SL, Paraná, rio Iguaçu. Hasemania nambiquara: MCP 38038, 2 of 4 paratypes, $1 \mathrm{c \& s}, 21.6-23.1 \mathrm{~mm}$ SL, Mato Grosso, rio Mutum, rio Juruena. Hasemania nana. MZUSP 39171, 23, 1 c\&s, 19.4-25.5 mm SL, Minas Gerais, ribeirão do Gado, rio São Francisco. MZUSP 39184, 30, 2 c\&s, 19.4-23.8 mm SL, Minas Gerais, córrego Gameleira, rio São Francisco. Hasemania piatan. MZUSP 104538, holotype, 54.0 mm SL, Bahia, municipality of Piatã (córrego Três Morros, bridge on road between Piatã and Núbia), tributary of rio de Contas. DZSJRP 11933, 20, paratypes, 3 c\&s, 23.1-33.5 mm SL, Bahia, municipality of Piatã, córrego Piabas, south of Piabas farm, tributary of rio de Contas. Hyphessobrycon negodagua. MZUSP 54589, 20, paratypes, 4 c\&s, 21.7-28.8 mm SL, Bahia, Iraquara, fazenda Pratinha, rio Pratinha. Hyphessobrycon taurocephalus. FMNH 54390, 23, paratypes, 30.1-42.5 mm SL, Paraná, Serrinha Paraná, rio Iguaçu. 


\section{Acknowledgments}

We thank Douglas C. Ribeiro (UNESP Ilha Solteira) for collecting some of the analyzed specimens and the Ichthyology Lab team (UNESP São José do Rio Preto) for helping in the fieldwork. FL is funded by CNPq (Proc. 305.946/2011-0), and FAPESP (Procs. 2004/0045-8 and 2012/ 23224-9).

\section{References}

Bertaco, V. A. \& F. R. Carvalho. 2010. New species of Hasemania (Characiformes: Characidae) from Central Brazil, with comments on the endemism of upper rio Tocantins basin, Goiás State. Neotropical Ichthyology, 8: 27-32.

Bertaco, V. A. \& L. R. Malabarba. 2007. A new species of Hasemania from the upper rio Tapajós drainage, Brazil (Teleostei: Characiformes: Characidae). Copeia, 2: 350-354.

Böhlke, J. 1958. Studies on fishes of the family Characidae-no. 14. A report on several extensive recent collections from Ecuador. Proceedings of the Academy of Natural Sciences of Philadelphia, 110: 1-121.

Carvalho, F. R. \& F. Langeani. 2013. Hyphessobrycon uaiso: new characid fish from the rio Grande, upper rio Paraná basin, Minas Gerais State (Ostariophysi: Characidae), with a brief comment about some types of Hyphessobrycon. Neotropical Ichthyology, 11: 525-536.

Ellis, M. D. 1911. On the species of Hasemania, Hyphessobrycon, and Hemigrammus collected by J. D. Haseman for the Carnegie Museum. Annals of the Carnegie Museum, 8: 148163.

Escobar, H. 2015. Drought triggers alarms in Brazil's biggest metropolis. Science, 347: 812.

Fink, W. L. \& S. H. Weitzman. 1974. The so-called cheirodontin fishes of Central America with descriptions of two new species (Pisces: Characidae). Washington, D.C., Smithsonian Institution Press, 1974, 46p. (Smithsonian Contributions to Zoology, no. 172).

Géry, J. 1972. Corrected and supplemented descriptions of certain characoid fishes described by Henry W. Fowler, with revisions of several of their genera. Studies on the Neotropical Fauna, 7: 1-35.

Géry, J. 1977. Characoids of the World. Neptune City, T.F.H. Publications, 672p.

International Union for Conservation of Nature (IUCN). 2001. IUCN Red List Categories and Criteria: Version 3.1. IUCN Species Survival Commission. IUCN, Gland, Switzerland and Cambridge, United Kingdom.

International Union for Conservation of Nature (IUCN). Standards and Petitions Subcommittee. 2011. Guidelines for Using the IUCN Red List Categories and Criteria. Version 9.0. Prepared by the Standards and Petitions Subcommittee, 87p. Available from: http://www.iucnredlist.org/documents/ RedListGuidelines.pdf (November, 2012).
Langeani, F. \& J. P. Serra. 2010. Coptobrycon bilineatus (Ellis, 1911) (Characiformes: Characidae): redescription and comments on its phylogenetic relationships. Neotropical Ichthyology, 8: 727-736.

Langeani, F., J. P. Serra, F. R. Carvalho, H. F. Chaves, C. P. Ferreira \& F. O. Martins. 2007. Fish, Hasemania crenuchoides Zarske and Géry, 1999 (Ostariophysi: Characiformes: Characidae): rediscovery and distribution extension in the upper rio Paraná system, Minas Gerais, Brazil. Check List, 3: 119-122.

Lima, F. C. T. \& P. Gerhard. 2001. A new Hyphessobrycon (Characiformes: Characidae) from Chapada Diamantina, Bahia, Brazil, with notes on its natural history. Ichthyological Exploration of Freshwaters, 12: 105-114.

Lima, F. C. T., L. R. Malabarba, P. A. Buckup, J. F. P. Silva, R. P. Vari, A. Harold, R. Benine, O. T. Oyakawa, C. S. Pavanelli, N. A. Menezes, C. A. S. Lucena, M. C. S. L. Malabarba, Z. M. S. Lucena, R. E. Reis, F. Langeani, L. Cassati, V. A. Bertaco, C. Moreira \& P. H. F. Lucinda. 2003. Genera Incertae Sedis in Characidae. Pp. 106-169. In: Reis, R. E., S. O. Kullander \& C. J. Ferraris, Jr. (Orgs.). Check list of the freshwater fishes of South and Central America. Porto Alegre, Edipucrs.

Malabarba, L. R. 1998. Monophyly of the Cheirodontinae, characters and major clades (Ostariophysi: Characidae). Pp. 193-233. In: Malabarba, L. R., R. E. Reis, R. P. Vari, Z. M. S. Lucena \& C. A. S. Lucena (Eds.). Phylogeny and classification of Neotropical fishes. Porto Alegre, Edipucrs.

Mirande, J. M. 2010. Phylogeny of the family Characidae (Teleostei: Characiformes): from characters to taxonomy. Neotropical Ichthyology, 8: 385-568.

Taylor, W. R. \& G. C. Van Dyke. 1985. Revised procedures for staining and clearing small fishes and other vertebrates for bone and cartilage study. Cybium, 9: 107-119.

Uieda, V. S., W. Uieda, A. B. C. Carneiro, S. A. Silveira, M. L. S. Melo \& R. H. Bornelas. 1987. Rede alimentar em duas comunidades de um riacho de água doce. Pp. 97-113. In: Seminário de Ciências da Fiube, 1, Uberaba, MG. Anais do Seminário de Ciências da Fiube.

Weitzman, S. H. \& S. V. Fink. 1985. Xenurobryconin phylogeny and putative pheromone pumps in glandulocaudine fishes (Teleostei: Characidade). Smithsonian Contributions to Zoology, 421: 1-121.

Weitzman, S. H. \& L. R. Malabarba. 1999. Systematics of Spintherobolus (Teleostei: Characidae: Cheirodontinae) from eastern Brazil. Ichthyological Exploration of Freshwaters, 10: $1-43$.

Zanata, A. M. \& J. P. Serra. 2010. Hasemania piatan, a new characid species (Characiformes: Characidae) from headwaters of rio de Contas, Bahia, Brazil. Neotropical Ichthyology, 8: 21-26.

Zarske, A. \& J. Géry. 1999. Hasemania crenuchoides, spec. nov. - ein neuer Salmler aus dem Bundesstaat Goias, Brasilien. Spixiana, 22: 91-96.

Submitted July 18, 2014

Accepted May 03, 2015 by Paulo Lucinda Published September 25, 2015 